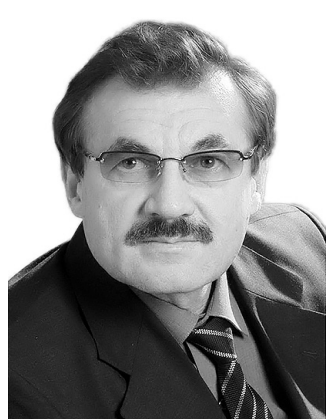

\title{
СИНЕРГЕТИКА ПРАВОВОГО АБСУРДУ НА ТЕРЕНАХ ЗЕМЕЛЬНИХ РЕФОРМ
}

\author{
ТЕРТИШНИК Володимир Митрофанович - доктор юридичних наук, \\ професор, академік Академії політичних наук України, (Університет митної
} справи та фінансів)

ORCID iD https://orcid.org/0000-0002-2993-0450 DOI:10.32782/LAW.2019.3.1

У статті на основі системного аналізу сучасного законодавства та законодавчих інічіатив з урахуванням міжнародних правових стандартів та прецедентної практики Європейсъкого суду з прав людини, розкриті проблеми забезпечення юридичної визначеності та розвитку інтегративних засад правової держави в питаннях землекористування. Подані пропозичй щодо забезпечення права на землю, показані ризики запровадження вільного обігу земель, запропоновані концептуальні моделі правових норм.

Земля дана людям на засадах природнъого права і не може бути товаром, оскільки вона не створена товаровиробником $i$ не може мати собівартості. Ï, як і свободу, не можна втрачати чи продавати. Земля знаходиться в єдності з природою, природними копалинами, а ї̈ можлива приватизаціє міжнародними корпораціями не гарантує від можливості нишівноӥ експлуатащй ï надр та інших ресурсів. Земля - цее унікальний скарб усъого суспільства, який може бути не тільки засобом організаиї земельного господарства, а й певним гарантом суверенітету держави та волі народу.

Ключові слова: земля, воля, прецедент, юридична визначеність, верховенство права.

Постановка проблеми

Україна декларує забезпечення верховенства права та прихильність до інших цивілізаційних цінностей. Земля є унікальним природним феноменом і одними 3 найбіль- ших цінностей українського народу право на які він невтомно і мужньо 3 жагою до життя виборював 3 давніх часів і дотепер, відстоював у лихоліттях історії, має зберегти для своїх потомків сьогодні. Сьогодні на Україну як хвилі накочуються нестримні правові реформи, які часто торкаються гарантій права народу на землю та при цьому не носять системного характеру, а часто містять корупційні та інші ризики усунення гарантій належного використання землі для суспільного блага.

Аналіз останніх досліджень і публікацій розкриває наявність проблем забезпечення права на землю і волю та розмаїття думок учених 3 цих проблем [7-21]. Проблема потребує системного, інтегративного аналізу.

Мета статті - визначення основних алгоритмів зміцнення гарантій захисту права українського народу на землю.

\section{Виклад основного матеріалу}

Земля $i$ воля є найбільшими надбаннями нашого народу, якому дісталась нелегка доля боротьби за ці цінності. Жага своєї землі та реальної волі здавна притаманні українцям, а благодатна земля наша сприяла появі на складних етапах історії легендарних отаманів визвольного руху, - то Іван Сірко, то Северин Наливайко, який у 1594-1596 pp. підняв найпотужніше повстання де однією 3 3 вимог була вимога мати свою землю і гос- 


\section{Теорія, історія держави і права, конституційне право}

подарювати на ній, оскільки усі тогочасні землі перебували у володінні шляхтичів, то Устим Кармелюк, то, Олесь Довбуш, то Костя Пестушко, Пилип Хмара, Мефодій Залізняк та інші повстанці Холодного Яру, то Нестор Махно... Жага своєї Землі та людської Волі були ідейними дороговказами і рушійними силами багатьох історичних звитяг.

Сьогодні нові політичні сили 3 більшовицьким запалом готові реалізувати давно забуті гасла, в тому числі і «землю селянам». I чим менше залишається селян на селі, тим усе частіше і радикальніше ставиться питання гарантування «для них» власності на землю.

У питаннях права на землю важливо здійснити системний аналіз усього пласту законодавчих актів та законотворчих ініціатив, що дасть змогу побачити можливі ризики негативних процесів та інші недоліки законодавчого поля.

В останніх законопроектах щодо земельних реформ усе частіше зустрічається пропозиція допустити до участі в ринку землі не тільки громадян України, а й юридичних осіб, зокрема українських агропромислових корпорацій, у тому числі і з іноземним капіталом. До Верховної ради України поданий законопроект, яким передбачено право продажу землі як громадянам України, так i юридичним особам, у складі яких, не виключення, можуть бути іноземці або наша «еліта» 3 подвійним громадянством Наразі йде енергійна робота 3 прийняття Закону України «Про обіг земель сільськогосподарського призначення».

Спробуємо на основі системного аналізу виявити можливі ризики такого підходу.

Принаймні нагадаємо, що Законом України від 23 березня 2017 р. №1983-VIII №2302-д, «Про внесення змін до деяких законодавчих актів України щодо підвищення рівня корпоративного управління в акціонерних товариствах» у правовому полі України запроваджується так звана процедура «squeeze-out» (сквіз-аут), тобто законна процедура примусового викупу акцій у дрібних акціонерів, особами, які стала домінуючим власником акцій.

У багатьох може виникати питання: «А до чого тут процедура «squeeze-out» (сквізаут)?. Логічно виникає риторичне запи- тання: «А чи передбачені якісь запобіжники від того, що спочатку українська юридична особа зв участі іноземних акціонерів та $з$ їх капіталом спочатку на законних підставах не придбає значний обсяг земель з вітчизняного земельного фонду, а уже потім окремі іï акціонери, застосовуючи процедуру «squeeze-out» (сквіз-аут), не викуплять акції дрібних акціонерів і не стануть одноособовими господарями відповідної юридичної установи та власниками придбаної нею української землі?».

Досі чіткої відповіді законодавців на це запитання немає. Здійснення самої процедури примусового викупу акції у дрібних акціонерів монополістами в багатьох аспектах мало чим відрізняється від ознак зловживання монопольним становищем, 6 різновидом узаконеного рейдерства. Наголосимо, що відповідно до ст. 41 Конституції України «Ніхто не може бути протиправно позбавлений права власності. Право приватної власності є непорушним. Примусове відчуження об'єктів права приватної власності... допускається лише в умовах воєнного чи надзвичайного стану». Спроба на законодавчому рівні дозволити розпродаж землі в умовах законодавчого хаосу та правозахисного колапсу може виявитись новітньою технологією «qqueeze-out» (сквіз-аут) по суті аферою віку.

Моделюємо ситуацію далі. Земля знаходиться в єдності 3 їі надрами, водними та іншими природними ресурсами, багата не тільки чорноземом, а й копалинами. Важливо звернути увагу на те, що згідно з ч. 1 ст. 90 Земельного кодексу України власник землі має між іншим право... «г) використовувати у встановленому порядку для власних потреб наявні на земельній ділянці загальнопоширені корисні копалини, торф, лісові насадження, водні об'єкти, а також інші корисні властивості землі»... Те, що є можливість власнику землі «пиляти ліс» чи добувати воду з мінеральних джерел, майже не визиває сумнівів. Але розпливчатий концепт - «використовувати інші корисні властивості землі», не тільки не відповідає принципу юридичної визначеності, а й може відкривати шлях до різних зловживань правом. 
Прикрий приклад ліквідації зачатків екологічної катастрофи на території Стебниківського «Полімінералу» у місті Стебник, яка могла призвести до зникнення мінеральних вод Трускавця і Східниці та зруйнувати окремі населені пункти даного регіону, та яка виникала через несумлінну розробку калійних солей, ярко показує, що дрібниць у питаннях землекористування не буває.

3 огляду на можливі обсяги можливого придбання землі юридичними особами за участі іноземних корпорацій виникає багато питань, зокрема чи передбачена система достатніх запобіжників, від можливості не стільки сіяти на землі волошки, а й добувати сланцевий газ, організувати золотодобування, добувати вугілля чи нафту ... Скупка значних обсягів землі іноземними чи офшорними компаніями може нести загрозу не тільки нищівної експлуатаий природних pecypcis, у тому числі добування сланцевого газу чи інших копалин, а й екологічній безпеці країни.

У земельних правовідносинах, навіть при вирішенні проблеми продажу землі, варто було 6 відповісти на такі головні питання: Хто, коли, для чого, як, за яку изну, з якими наслідками?

Хто буде організовувати продажу землі? Поряд з сумлінними держслужбовиями, це не очищені від корупції чиновники 3 повним хаосом законодавчого поля та колапсу правоохоронних органів. Мабуть, логічно ставити питання про необхідність забезпечити дієву антикорупційну політику в державі в цілому та у сфері землекористування, зокрема, провести аудит землі та належний державний контроль за земельними ресурсами та законністю виконання юрисдикції державними інституціями. Скасування функції прокуратури щодо нагляду за законністю в діяльності органів влади і місцевого самоврядування не отримало досі нового інституційного наповнення. Варіанти зі створенням інституту префектів чи омбудсменів можуть розглядатись при умові їх створення і забезпечення дієвості ще до відкриття вільного обігу землі. Але дієвість має бути забезпечена і процедурно, і матеріально, і засобами протидії можливого силового спротиву рейдерів чи інших зацікавлених у незаконних діях осіб.

Коли запроваджується вільний обіг землі?В умовах військового конфлікту та правового безладу (одні воюють за землю в окопах інші збираються їі розпродавати). Не на разі.

EСПЛ у справі «Зеленчук і Цицюра проти Україн» не випадково зазначив, що рішення Суду не слід розуміти як таке, що зобов'язує невідкладно запровадити необмежений ринок земель сільськогосподарського призначення в Україні (п. 150).

Для чого пропонується здійснити розпродаж землі? Оприлюднена мета вільного обігу землі не співпадає з інтересами суспільства. Поспішність та утаємниченість роботи щодо законопроектів показують на хибні кроки.

У порівняльно-правовому контексті слід звернути увагу на те, що у семи європейських держав (Австрія, Угорщина, Аатвія, Литва, Польща, Словацька Республіка та Словенія) для передання права власності на землю або надання переваги перед іншими покупцями, від покупця вимагається освіта або попередній досвід роботи в сільськогосподарському секторі.

Досвід країн Европи, де земля ніколи не відбиралась насильно у землеробів, показує, що тут створюються певні запобіжники від огульного іiі розпродажу. Наприклад, процедура надання дозволу на придбання землі в Австрії спрямована на збереження ефективного використання землі для сільського господарства, тому для отримання дозволу покупець має забезпечити гарантії того, що він або вона дійсно сумлінно оброблятиме придбану землю.

До речі, у більшості цивілізованих країн 3 найбільшим добробутом громадян земля в переважній більшості знаходиться в державній власності, а сільське виробництво базується на орендних відносинах та розвиненому фермерстві.

У нашій країні ні чинне законодавство, ні існуючі законопроекти не передбачають ефективної і достатньої системи запобіжників від нищівної експлуатащиї природних ресурciв, у тому числі шляхом добутку сланцевого газу чи інших копалин при запровадженні існуючих пропозицій щодо скупки значних 


\section{Теорія, історія держави і права, конституційне право}

обсягів землі юридичними особами з участю іноземних компаній.

Як моделюється продаж землі? Без завершення створення системного всеохоплюючого земельного кадастру, жорсткого контролю та надійних гарантій для вже працюючих на землі, в умовах наявності хаосу з існуючими документами розпаювання землі в селах, існуючих проблем об'єднання громад та функціонування органів місцевого самоврядування.

При об'єднанні сільських громад багато селян не можуть знайти сліди своїх орендних угод і інших документів, якими підтверджено їх право на землю. Вони не можуть домогтись не тільки орендної плати зі свого паю, а й довести, що вони «власники землі». У жителів села виникають значні проблеми оформлення документів про право на земельну частку, установлення кадастрового номера їх земельного паю. Тут непочатий край роботи слідчим органам і антикорупційним інституціям.

Мабуть, перш за все, потрібно завершити створення системного земельного кадастру, створити державний земельний банк, провести аудит земель, усунути наслідки рейдерських та шахрайських дій 3 паями громадян та ретельно перевірити угоди щодо оренд землі, перевірити наскільки належним чином використовується земля орендаторами, забезпечити виконання ст. 121 Земельного кодексу України щодо права українських громадян на безоплатну передачу ї земельних ділянок із земель державної або комунальної власності, а, разом 3 тим, забезпечити в ініційованих реформаторських процесах дотримання ст. 22 Конституції України (недопущення звуження існуючих прав, у тому числі і спільного права народу на власність над землею).

За яку изіну буде продаватись найкраща на планеті земля? За найнижчу в Европі, фактично за безцінь (тоді як 3 роками ціна на землю буде неухильно збільшуватись).

У вирішенні дилеми «продавати чи господарювати» варто знати, що якщо сорок млн гектарів орної землі не продавати, а навіть просто здавати в оренду по триста доларів за гектар, можна отримувати 12 млрд доларів щорічно до бюджету держа- ви. Якщо господарювати 3 розумом - можна більше. Якщо ж продати всю цю землю один раз, можна залишитись без України .... Наша земля кращий інвестор і гарант незалежності України. Володимир Іванович Вернадський називав нашу золоту ораницю «четвертим царством» природи та ії біокосним тілом, а сенатор Джон Маккейн невипадково зізнавався: «Я думаю, що вода і земля стануть питаннями №1 у 21 столітті».

Українська земля - найкраща земля на планеті, це скарб, який створювався не одним тисячоліттям та дістався нам усім у спадщину від наших пращурів, дідів і прадідів, скарб, який з роками набирає цінності в глобальному світі на виснажливому глобальному ландшафті планети. I ми не маємо права залишити наших внуків без можливості користуватись таким спадком.

3 якими наслідками буде реалізований розпродаж землі в сучасних реаліях? За існуючих обставин - 3 такими ж, як і приватизація заводів та інших підприємств, але 3 набагато більшою шкодою державній безпеці, добробуту та суверенітету.

Зазначимо, що в Резолюції 1803 (XVII) Генеральної Асамблеї ООН «Невід'ємний суверенітет над природними ресурсами» (14 грудня 1962 року) записано «Право народів i націй на невід'ємний суверенітет над їх природними багатствами і ресурсами повинно здійснюватися в інтересах їх національного розвитку та благополуччя населення».

Здобутком народу України є положення $\mathrm{cm}$. 13 Конституиій Украӥни: «Земля, ії надра, атмосферне повітря, водні та інші природні ресурси, які знаходяться в межах території України, природні ресурси їі континентального шельфу, виключної (морської) економічної зони є об'єктами права власності Українського народу. Від імені Українського народу права власника здійснюють органи державної влади та органи місцевого самоврядування в межах, визначених цією Конституцією».

Частина перша статті 14 Конституції України передбачає, що земля є основним національним багатством і перебуває під особливою охороною держави. Тобто земля не розглядається як звичайний товар, у традиційному розумінні «купівлі-продажу 
товарів». Особлива охорона землі потребує системного законодавчого закріплення.

У нас немає права залишити внуків і правнуків без своєї землі.

Земля - це унікальний скарб усього суспільства, який може бути не тільки засобом організації земельного господарства, а й певним гарантом права на волю та суверенітет держави.

Вважаємо за доцільне ч. 1 ст. 3 Конституції України викласти в такій редакції: «入юдина, її життя і здоров'я, воля, честь і гідність, недоторканність і безпека, іï права і свободи визнаються в Україні найвищою соціальною цінністю».

Пропонується ст. 14 Конституції України викласти таким чином: «Земля є основним і невідчужуваним спільним національним багатством українського народу, що перебуває під особливою охороною держави. Земля є гарантом волі народу та суверенітету української держави, не може розглядатись як товар у цивільних угодах.

Право власності на землю сільськогосподарського призначення гарантується i реалізується виключно лише для громадян України і лише щодо надання права володіння і користування землею відповідно до закону, за виключенням вилучення такої землі державою для суспільних потреб. Право на землю сільськогосподарського призначення для громадян України реалізується наданням їм права на безстрокову оренду землі для використання за призначенням, передачі даного права в спадщину, передачі права власності на землю до держави через Земельний банк України на договірних визначених в законі умовах».

\section{Висновки}

Право українського народу на землю 6 інтегративною засадою української правової держави, яка потребує чіткого доктринального осмислення та юридичного визначення в Конституції України, деталізації в інститутах окремих галузей права. Галузеве законодавство потребує конкретизації гарантій забезпечення права на волю та землю з урахуванням природнього права та конституційних засад державотворення, системного аналізу існуючого правового поля, усунення юридичних фікцій і колізій.

Перспективи подальшого розгляду проблеми вбачаються в розкритті крізь призму принципів правової визначеності інститутів права на землю та розробки пропозицій щодо удосконалення окремих інститутів законодавства.

\section{Література}

1. Конституція України: Прийнята Верховною Радою України 28 червня 1996 р. Відомості Верховної Ради України. 1996.№ 30 .

2. Европейська конвенція про захист прав і основних свобод людини від 04.11.96. Офіційний вісник України. 1998. №13.

3. Резолюція 1803 (XVII) Генеральної Асамблеї ООН «Невід'ємний суверенітет над природними ресурсами» (14 грудня 1962 року)

4. Рішення Европейського суду з прав людини. URL: http://old.minjust.gov.ua/19612

5. Аналіз проектів законодавчих актів щодо обігу землі. URL: http://growford.org.ua/5 zakoniv_vid vlady.pdf? fbclid = I w A R 0 W 8 K X gylYVerQp2Vpx5AuyD4haK 1 C50N1-52 Zf1XRBCIqOApIdPkizY

6. Земельний кодекс Iзраїлю. URL: http://isradem.com/index.php?newsid =532\&f bclid=IwAR0XzCzcD2aBbk4PZ8Y1ykAWvoB 0t6qBfWMfU53caU-W7zETxWUHZY Jvc88\#. XZYFTILwQCY.facebook

7. Базів В. Українсъка земля у горнилі грядуших викликів глобального виживання людства. Ua.info. URL: https://uainfo. org/blognews/1493035896-skarb-natsiyividkritiy-list-petru-poroshenku.html?fbclid = IwAR1F8epRAVTKvvIRVEIntDzoR2Qu w53c3frBgCsGsmBjRb3T6qK6rjRWRM

8. Беженар Г. М., Бердніков С. С., Бондар А. О., Гавриш Н. С., Гуревський В. К. Земельне право Украйни: Підручник. К.: Істина, 2003. 446 c.

9. Земельне право України: підручник [Г. І. Балюк, Т. О. Коваленко, В. В. Носік та ін.: за ред. В. В. Носіка]. К.: Видавничо-поліграфічний центр «Київський університет», 2008. 511 c. 


\section{Теорія, історія держави і права, конституційне право}

10. Килимник I. І., Міхно О. І. Земельне право Украйни: навч. посібник. Харків: ХНУМГ ім. О. М. Бекетова, 2015. 166 с.

11. Коломоєць Т. О., Колпаков В. К. Науково-практичний коментар Закону Украйни «Про запобігання корупиіӥ». Київ: Видавничий дім «Гельветика». 2019. 588 с.

12. Конституційне право України : навч. посібник [для підгот. до іспиту за кредитномодульною системою навчання]. 2-е вид., перероб. і доп. / В. О. Боняк, В. А. Завгородній, А. В. Самотуга, ᄉ. А. Філяніна. Дніпро : Дніпроп. держ. ун-т внутр. справ, 2017. 293 с.

13. Кулинич П. Ф. Право власності на землю. Юридична енциклопедія : [в 6-ти т.] / ред. кол. Ю. С. Шемшученко (відп. ред.) та ін. К.: Українська енциклопедія ім. М. П. Бажана, 1998-2004. 768 с.

14. Кущ А. Никаких инвестиций. Почему украинскую землю будут покупать род пальмами. Деловая столица. 18 Октября 2019. URL: http://www.dsnews.ua/economics/nikakih-investitsiy-pochemu-za-ukrainskuyu-zemlyu-budut-borotsya-18102019170500

15. Мельник Я. Я. Особливості дій режиму процесуальної безпеки щодо земельних спорів у иивільному судочинстві. Вісник Запорізького національного університету. 2015. № 4 (II). C. 7-14.

16. Семчик В. І., Кулинич П. Ф., Шульга М. В. Земельне право Украйни: Академічний курс: підруч. для студ. юрид. спец. вищ. нави. закл. К.: Ін Юре, 2008. 600 с.

17. Сливка С. С. Філособія права: Нави .посіб. К.: Атіка, 2012.

18. Тертишник В. М. Воля в інтегративній системі засад правової держави. Актуальні проблеми вітчизняної юриспруденції. Спеціальний випуск. 2019. Ч. 1. С. 15-19.
19. Тертишник В. М. Земля в начіональній доктрині державотворення. Наше право. 2019. №1. C. 5-10.

20. Тертишник В. М., Корнієнко М. В. White-Collar Crime в «модних піджаках». Свропейські перспективи. 2018. №3. С. 55-54. URL: http://ep.unesco-socio.in.ua/wp-content/ uploads/2018/12/zhurnal-yevropejskiperspektyvy-2018-3.pdf

21. Ягунов Д. Практика ЕСПЛ (питання кримінального та иивільного судочинства, захисту власності, приватного і сімейного життя). 4-те вид., перероб, i доп. Одеса: Фенікс, 2019. $502 \mathrm{c}$.

Vladimir Tertyshnyk.

Synergy of legal absurdity on the territory of land reforms.

The article on the basis of systemic analysis of modern legislation and legislative initiatives taking into account international legal standards and case practice of the European Court of Human Rights, disclosed the problems of ensuring legal certainty and Development of integrative principles of the legal State in matters land use. Submitted proposals for the right to land, showing the risks of introduction of free land, proposed conceptual models of legal norms.

Earth is given to people on the basis of natural law and can not be a commodity, because it is not established commodity producer and can not have a cost. It is like freedom and can not be lost or sold. The Earth is in unity with nature, natural in minerals, and its possible privatization by international corporations does not guarantee the possibility of crushing exploitation of its subsoil and other resources. Land-a unique treasure of the entire society, which can be not only a means of organizing land economy, but also a certain guarantor of sovereignty of the State and the will of the people.

Keywords: Earth, will, precedent, legal certainty, the rule of law. 